\title{
Time trend estimation of food consumption in repeated studies with different versions of food questionnaire among Brazilian schoolchildren aged 7 to 11 years
}

\author{
Estimativa da tendência temporal do consumo alimentar em \\ estudos repetidos com diferentes versões do questionário alimentar \\ entre escolares brasileiros de 7 a 11 anos
}

Emil Kupek (https://orcid.org/0000-0001-6704-1673) ${ }^{1}$

Rafaela Liberali (https://orcid.org/0000-0002-9471-7648) ${ }^{2}$

Maria Alice Altenburg de Assis (https://orcid.org/0000-0002-5383-3714) ${ }^{3}$

${ }^{1}$ Departamento de Saúde Pública, Universidade Federal de Santa Catarina. Campus Universitário Trindade. 88040-900. Florianópolis SC Brasil. emil.kupek@ufsc.br

${ }^{2}$ Programa de PósGraduação em Ciências Médicas, Universidade Federal de Santa Catarina.

Florianópolis SC Brasil.

${ }^{3}$ Programa de Pós-

Graduação em Nutrição.

Centro de Ciências da

Saúde, Universidade

Federal de Santa Catarina.

Florianópolis SC Brasil.

\begin{abstract}
Longitudinal study, whose objective was to evaluate of the time trend in food consumption across the 2002-2015 period in schoolchildren aged 7 to 11 years, covered five food surveys in Florianopolis, southern Brazil. Methodological differences across the surveys (typical vs. previous day food consumption, pen-and-paper versus computer screen presentation) and some known risk factors, were adjusted for statistically. Offset by maximum food/beverage consumption per day allowed comparability of a varying number of food components in a food group over survey years. Significant reduction in some healthy (fruits and animal proteins) and unhealthy diet markers (sodas, sugary drinks, sweets) was observed over the 2013-2015 period compared with the 2002 and 2007 data. Computer screen presentation of the food questionnaire systematically reduced the reporting frequency compared to the pen-and-paper presentation. Converting frequency reports into rates and using contrast analysis allowed time trend estimation based on food questionnaires with different presentation modes, varying number of items within food group over survey years, and variations in probabilistic sampling procedures.
\end{abstract}

Key words Schoolchildren, Diet surveys, Food consumption, Longitudinal studies
Resumo Estudo longitudinal cujo objetivo foi avaliar a tendência temporal do consumo alimentar no período 2002-2015 em escolares de 7 a 11 anos, abrangendo cinco inquéritos alimentares em Florianópolis, Sul do Brasil. Foi ajustado para diferenças metodológicas (consumo alimentar típico vs. dia anterior, caneta e papel vs. apresentação no computador) e alguns fatores de risco. A compensação pelo consumo máximo de alimentos/bebidas por dia permitiu a comparabilidade de um número variável de componentes de alimentos em um grupo de alimentos ao longo dos anos da pesquisa. Foi observada redução em alguns marcadores de dieta saudável (frutas e proteinas animais) $e$ não saudáveis (refrigerantes, bebidas açucaradas, doces) no período de 2013-2015, em comparação com os dados de 2002 e 2007. A apresentação do questionário alimentar na tela do computador reduziu sistematicamente a frequência de relatórios em comparação com a apresentação em papel e caneta. A conversão de relatórios de frequência em taxas e o uso de análise de contraste permitiram a estimativa de tendência de tempo com base em questionários de alimentos com diferentes modos de apresentação, número variável de itens dentro do grupo de alimentos ao longo dos anos da pesquisa e variações nos procedimentos de amostragem probabilística.

Palavras-chave Escolares, Inquéritos sobre dietas, Consumo de alimentos, Estudos longitudinais 


\section{Introduction}

One of the most frequent complaints of researchers in nutritional epidemiology is the impossibility of comparing the findings from the studies based on different methodologies. The latter include different dietary assessment methods (e.g. food frequency questionnaire, $24 \mathrm{~h}$ dietary recall/ record, food diary), different definitions of the period analysed (e.g. last year, last month, previous day, typical day), varying number of days, weekdays and/or weekend days, the source of diet report (e.g. parents and children, only children), varying number and definition of food items or food groups, the differences in the target population and sampling, in questionnaire presentation (e.g. pen-and-pencil, computer/tablet/smartphone screen), in instructions to the respondents, and in the choice of statistical methods used to analyse the data ${ }^{1-4}$.

A special case of methodological differences emerges from evolving versions of the same questionnaire over time to accommodate the changes in the food choices and eating behaviour. With nutritional surveillance and monitoring becoming more prominent as an essential tool in combating obesity worldwide ${ }^{5-7}$, addressing the above issues in a quantitative analysis becomes even more important. In particular, time trend analysis over a period sufficiently long (e.g. over a decade) to capture significant changes in dietary intakes is very likely to encounter aforementioned methodological differences as survey means and presentation mode change rapidly with scientific and technological advances.

Our research team has developed and validated the Typical Day Food and Physical Activity questionnaire (acronym DAFA in Portuguese) ${ }^{8}$, the Previous Day Food Questionnaire (PDFQ) (Versions 2 and 3) $)^{9,10}$, and the Food Consumption and Physical Activity for Schoolchildren (acronym WebCAAFE in Portuguese) $)^{11-14}$ which evolved from a pen-and-pencil food frequency questionnaire (FFQ) to a web-based food and physical activity questionnaire.

Funding agencies encourage collaboration between the researchers working in the same area to use financial and human resources more rationally ${ }^{15}$. In this context, quantitative data synthesis strategies such as meta-analysis have been highly appreciated, although a more flexible framework has been put forward, capable of evaluating time trend even for relatively small and heterogeneous groups $^{15-19}$.

The objective of this work is to present regression framework for estimating time trend in food consumption and eating behaviour with different versions of a food questionnaire and apply it to analyse food/beverage consumption trends over the 2002-2015 period among 7-11-year-old schoolchildren in Florianopolis, southern Brazil.

\section{Methods}

Two longitudinal studies provided the data for this analysis: one from the 2002 and 2007 surveys, and the other from the annual surveys over the 2002-2015 period (Table 1). The studies were conducted according to the guidelines set out in the Code of Ethics of the World Medical Association (Declaration of Helsinki) and all procedures involving human subjects were approved by the Human Studies Committee of the Federal University of Santa Catarina (protocols 037/02, $028 / 06,2,250 / 11$ ). Written informed consent was obtained from the parents and oral assent was obtained from the children.

In 2002, 16 elementary schools stratified by type (public, private) and city region (central, coastal) were randomly sampled from 122 eligible schools with children enrolled in the 2nd to 5 th grades. In the second stage of the sampling, the school classes were randomly sampled within selected schools and all children in those classes were invited to answer the DAFA FFQ. The final sample comprised 2,936 schoolchildren (1,988 from public and 948 from private schools $)^{20}$.

All 16 schools were invited to participate in the second survey in 2007. Fourteen schools accepted the invitation and the two that refused were replaced by other similar schools; one more public school was included in the sample. The target population was all schoolchildren between the second and the fifth grade in municipal elementary schools. The final sample obtained consisted of 1,232 children from 17 schools (782 from public and 450 from private schools $)^{21}$.

The 2013-2015 surveys were restricted to public schools and included about $95 \%$ of these. Few schools without a computer room were excluded from data collection. Primary sampling units were 2 nd to 5 th-grade classrooms, all of which participated in the surveys. Mentally handicapped and visually impaired children were excluded from the survey. Among the children with informed consent and complete information on age, sex, weight, height, and food consumption, $9.1 \%$ were excluded because of implausible dietary data such as reporting less than four food items per day or out of the mean \pm 3 standard deviations (SD) interval ${ }^{14}$. 
Table 1. Characteristics of the food questionnaires applied in Florianópolis, 2002-2015.

\begin{tabular}{|c|c|c|}
\hline $\begin{array}{l}\text { Questionnaire } \\
\text { acronym } \\
\text { (version), year }\end{array}$ & $\begin{array}{l}\text { Application } \\
\text { mode }\end{array}$ & Sampling \\
\hline DAFA, 2002 & Pen and paper & $\begin{array}{l}9 \text { public and } 7 \text { private schools randomly selected from the total of } 78 \\
\text { and } 44 \text { schools with } 2^{\text {nd }} \text { to } 5^{\text {th }} \text { grade pupils, respectively }(\mathrm{N}=2,959)^{1}\end{array}$ \\
\hline PDFQ-3, 2007 & Pen and paper & $\begin{array}{l}\text { All schools which participated in } 2002 \text { invited but two private schools } \\
\text { refused and were replaced by neighboring schools }(\mathrm{N}=1,592)^{1}\end{array}$ \\
\hline WebCAAFE, 2013 & $\begin{array}{l}\text { Computer } \\
\text { screen }\end{array}$ & $\begin{array}{l}34 \text { out of } 37 \text { schools with computer room invited and took part, with } \\
\text { sampling pool of } 6,9462^{\text {nd }} \text { to } 5^{\text {th }} \text { grade pupils }(\mathrm{N}=2,093)^{1}\end{array}$ \\
\hline WebCAAFE, 2014 & $\begin{array}{l}\text { Computer } \\
\text { screen }\end{array}$ & $\begin{array}{l}34 \text { out of } 36 \text { schools with computer room invited and took part, with } \\
\text { sampling pool of } 71202^{\text {nd }} \text { to } 5^{\text {th }} \text { grade pupils }(N=2,149)^{1}\end{array}$ \\
\hline WebCAAFE, 2015 & $\begin{array}{l}\text { Computer } \\
\text { screen }\end{array}$ & $\begin{array}{l}35 \text { out of } 36 \text { schools with computer room invited and took part, with } \\
\text { sampling pool of } 7,1242^{\text {nd }} \text { to } 5^{\text {th }} \text { grade pupils }(N=25,59)^{1}\end{array}$ \\
\hline
\end{tabular}

In 2002 the children responded the DAFA FFQ. It was a pen-and-paper pictorial questionnaire which asked the children to check all of the 16 food drawings (Table 2) consumed on a typical day. The DAFA FFQ was validated against the $24 \mathrm{~h}$ recall method in a sample of schoolchildren from the city of Florianopolis and showed moderate agreement ${ }^{8}$.

In 2007, the children answered the third version of the Previous Day Food Questionnaire (PDFQ-3), a new version of the questionnaire applied in 2002. New elements were the following: a) children were asked to mark the food/ food group items consumed on the previous day instead of on a typical day, b) evening snack was added as the sixth eating event and included the period between dinner and going to sleep, and c) four more drawings were added (green leaves, coffee with milk, vegetable soup, salty crackers) and one was withdrawn (egg). Trained researchers instructed the children to mark their typical food/beverage consumption on the previous day by crossing or circling the drawings. PDFQ-3 contained 32 food/beverage items (Table 2) and was previously validated through direct observation of school meals, demonstrating reasonable average sensitivity (probability of correctly reporting a food intake) of $70.2 \%$ and excellent average specificity (probability of correctly not reporting a food intake) of $96.2 \%{ }^{10}$.

Since 2013, the questionnaire expanded the number of food/beverage items to 32, substituted the pen-and-paper mode with computer screen and used the Internet to access the questionnaire ${ }^{11-13}$. An animated robot-like Avatar guided children while answering the questions. Before closing the block on food consumption, the pupils were presented with a tray of the foods/beverages they selected for each meal and asked to check and revise their answers if necessary. The validation study showed $43 \%$ of matches between WebCAAFE and observed dietary intake in school, as well as $29 \%$ of intrusions and $28 \%$ of omissions, putting this questionnaire's accuracy close to that of other similar instruments ${ }^{22}$.

The food selection for these questionnaires was motivated by the food patterns of children in this age group already consolidated in the literature but also included the foods presented in school menus and those recommended in the guidelines for Brazilian population ${ }^{23,24}$.

\section{Data analysis}

Private school pupils were excluded from the analysis in the present study to reduce the sample heterogeneity, so that the analytical sample was representative of the 2 nd to 5 th-grade public school pupils in the municipality of Florianopolis, the Santa Catarina state capital, Brazil. Survey parameters included schools as primary sampling units and probability weights for selecting schools and children within schools in the twostage random sampling design. All pupils from selected classes were invited to respond to the food frequency questionnaires (FFQs).

The clustering of pupils within schools was addressed by including this source of co-variation within primary sampling units among the survey design parameters. Hubert-White robust 
Table 2. Food and beverage items by survey year.

\begin{tabular}{|c|c|c|c|c|}
\hline \multicolumn{2}{|c|}{ Food/beverage } & \multicolumn{3}{|c|}{ Survey year } \\
\hline Group & Item & 2002 & 2007 & 2013-2015 \\
\hline \multirow{5}{*}{$\begin{array}{l}\text { Diary } \\
\text { products }^{\mathrm{a}}\end{array}$} & Milk & $\mathrm{x}$ & $\mathrm{x}$ & $\mathrm{x}$ \\
\hline & Coffee with milk & & $\mathrm{x}$ & $\mathrm{x}$ \\
\hline & Cheese & $\mathrm{x}$ & $\mathrm{x}$ & $\mathrm{x}$ \\
\hline & Yogurt & $\mathrm{x}$ & $\mathrm{x}$ & $\mathrm{x}$ \\
\hline & Egg & $\mathrm{x}$ & & $\mathrm{x}$ \\
\hline \multirow{3}{*}{$\begin{array}{l}\text { Fruits and } \\
\text { vegetables }^{\text {b }}\end{array}$} & Fruits & $\mathrm{x}$ & $\mathrm{x}$ & $\mathrm{x}$ \\
\hline & Green leaves & & & $\mathrm{x}$ \\
\hline & Vegetable soup & & & $\mathrm{x}$ \\
\hline \multirow[t]{7}{*}{ Fast food ${ }^{c}$} & Hamburger & $\mathrm{x}$ & & $\mathrm{x}$ \\
\hline & Pizza & $\mathrm{x}$ & & $\mathrm{x}$ \\
\hline & Salty snack & $\mathrm{x}$ & & $\mathrm{x}$ \\
\hline & French fries & $\mathrm{x}$ & & $\mathrm{x}$ \\
\hline & Instant pasta & & & $\mathrm{x}$ \\
\hline & Sausage & & & $\mathrm{x}$ \\
\hline & Nuggets & & $\mathrm{x}$ & $\mathrm{x}$ \\
\hline \multirow{4}{*}{$\begin{array}{l}\text { Animal } \\
\text { protein }\end{array}$} & Meat & $\mathrm{xx}$ & & $\mathrm{x}$ \\
\hline & Chicken & $\mathrm{xx}$ & & $\mathrm{x}$ \\
\hline & Fish & $\mathrm{xxx}$ & & $\mathrm{x}$ \\
\hline & Seafood & $\mathrm{xxx}$ & & $\mathrm{x}$ \\
\hline \multirow{7}{*}{$\begin{array}{l}\text { Major sources } \\
\text { of } \\
\text { carbohydrates }\end{array}$} & Bread & $\mathrm{xx}$ & & $\mathrm{x}$ \\
\hline & Cheese bread & & & $\mathrm{x}$ \\
\hline & Porridge & & & $\mathrm{x}$ \\
\hline & Pasta & $\mathrm{xx}$ & & $\mathrm{x}$ \\
\hline & Cereals & & & $\mathrm{x}$ \\
\hline & Rice & $\mathrm{x}$ & $\mathrm{x}$ & $\mathrm{x}$ \\
\hline & Beans & $\mathrm{x}$ & $\mathrm{x}$ & $\mathrm{x}$ \\
\hline \multirow[t]{3}{*}{ Sweets ${ }^{\mathrm{d}}$} & Cake without cream & & & $\mathrm{x}$ \\
\hline & Cake with cream & & & $\mathrm{x}$ \\
\hline & Biscuits & $\mathrm{xx}$ & & $\mathrm{x}$ \\
\hline \multirow[t]{3}{*}{ Sugary drinks ${ }^{\mathrm{e}}$} & Sodas & $\mathrm{x}$ & & $\mathrm{x}$ \\
\hline & Fruit juice & $\mathrm{x}$ & & $\mathrm{x}$ \\
\hline & Chocolate milk & $\mathrm{x}$ & & $\mathrm{x}$ \\
\hline
\end{tabular}

a Milk/cheese, yogurt, eggs in 2002; added coffee with milk and omitted eggs in 2007; cheese, eggs and yogurt presented milk as separate icons in 2013-2015. ${ }^{\mathrm{b}}$ Fruits and green leaves/vegetable soup in 2002; in addition to fruits, green leaves, vegetables and vegetable soup presented as separate icons in 2007; fruits, vegetables and green leaves kept in 2013-2015. ' Hamburger/ pizza and French fries in 2002; salty snacks added in 2007 and instant pasta, nuggets and canned food in 2013-2015. ${ }^{\mathrm{d}}$ Included chocolate bars and powder in 2002 and 2007; presented four separate icons in 2013-2015: chocolate drinks, biscuits without cream, biscuits with cream and cakes. ${ }^{\text {e }}$ Sodas and sugar-added fruit juice.

Source: Authors.

maximum likelihood estimators of food consumption rate per day and corresponding 95\% confidence intervals (CI) were calculated by statistical package Stata $13.0^{25}$.
Main outcomes included the mean frequency of food consumption (MFC) for selected single food/beverage items (fruits, beans, sodas, milk/ cheese) and food groups (dairy products, meat/ chicken/fish/seafood, fruits and vegetables, fast food, sweets, sugary drinks). Key exposure variables were questionnaire presentation mode (pen-and-pencil vs. computer screen) and the instruction given to the pupils regarding the period of food consumption (previous day vs. typical day). Control variables included child age (rounded to full year), sex, school shift, family income and the day of the week the survey was applied. By definition, main outcomes had no missing values as unmarked food items were considered not consumed.

Ordinary least squares regression was used to estimate the linear change in the MFC. The means were weighted by the inverse of their variance estimated for each survey year and were not initially adjusted for the control variables. Also, multivariate Poisson regression, adjusted for the control variables, was used to obtain survey year point estimates and post hoc contrast estimates of interest. The maximum number of foods/ beverages per day was used as an offset in Poisson regression, thus producing rate estimates, hereby denominated as food consumption rate (FCR) per day. The rate allows comparability of a varying number of meals (five in the 2002 questionnaire vs. six since 2007) and food group components (e.g. adding green leaves to the fruit $\&$ vegetable group). The offset was the product of the number of meals and the number of food components for food groups, or simply the number of meals per day for single food/beverage items, keeping in mind that respondents were asked only whether these items were consumed or not for each meal/snack. In both cases, the offset was the maximum number of items achievable per day.

Additional statistical analyses were performed to evaluate the time-related changes and were guided by two major issues: the effect of asking about typical versus previous day food/ beverage consumption and of pen-and-paper versus computer screen presentation of the questionnaire. The former question was addressed by comparing the 2002 and 2007 FCR estimates because both used the pen-and-paper version, thus holding this factor constant while varying the question form. The 2013-2015 versus 2007 contrast was used to evaluate the presentation mode effect as the question mode was held the same within the periods compared. All contrasts were 
conditional on the adjusted Poisson regression estimates in a post hoc analysis.

Furthermore, interval regression was used to estimate likely MFC in 2002 had the respondents been asked to check out the food/beverage items consumed on a typical day instead of on a previous day. To define the upper bound for this regression, the reasoning was that the typical day question tended to expand the food report to the number of items ever consumed, at least for some children, because averaging a variety of these items over an undefined period was a daunting cognitive task. Without understanding the meaning of the word "typical", children are likely to ignore this part of the question and answer the remaining part of "What do you eat on a typical day?", which is probably interpreted as "any day" and is thus likely to stimulate intrusion (false positive) reports. Consequently, the upper bound was set to the reported 2002 food/beverage consumption, whereas the lower bound was set to the median 2007 consumption for each combination of the aforementioned independent variables. Fitted values from the interval regression were assigned precision equal to the inverse of their variance (so-called "analytical weights") in 2002 to account for their hypothetical nature as these values were not actually reported, while all other data were observed. Time trend and contrast analyses used these hypothetical 2002 estimates to align the FFQ period of food/beverage consumption to the previous day for all surveys. Statistical significance for the type I error was set at $<0.05$.

\section{Results}

The analytical sample size was about twice as big over the 2013-2015 period compared to the average of the 2002 and 2007 survey (Table 3). Of note, there was a six-fold increase in the percentage of the implausible food reports excluded from the analysis, from about $0.5 \%$ in the first two surveys to approximately $3 \%$ in the subsequent surveys.

MFC per day and its variation were more homogenous in the 2013-2015 period compared to the 2002-2007 period when pen-and-pencil

Table 3. Sociodemographic characteristics of 7-11-year-old schoolchildren from public schools by food survey year in Florianópolis.

\begin{tabular}{|c|c|c|c|c|c|c|c|}
\hline \multirow{2}{*}{ Characteristic } & \multirow{2}{*}{ Description } & \multicolumn{5}{|c|}{ Survey year } & \multirow{2}{*}{ Total } \\
\hline & & 2002 & 2007 & 2013 & 2014 & 2015 & \\
\hline \multicolumn{2}{|c|}{ Sample size obtained } & 1386 & 950 & 2093 & 2149 & 2559 & 9137 \\
\hline \multicolumn{2}{|c|}{ Analytical sample size } & 1376 & 947 & 2025 & 2070 & 2490 & 8908 \\
\hline \multicolumn{2}{|c|}{ Excluded from analysis $(\%)^{1}$} & 0.72 & 0.32 & 3.25 & 3.68 & 2.70 & 2.51 \\
\hline \multirow[t]{2}{*}{ Sex } & Girls & 48.05 & 51.76 & 48.69 & 50.87 & 49.16 & 50.29 \\
\hline & Boys & 51.95 & 48.24 & 51.31 & 49.13 & 50.84 & 49.71 \\
\hline \multirow{5}{*}{$\begin{array}{l}\text { Age } \\
\text { (years) }\end{array}$} & $7(6.50-7.49)$ & 08.21 & 08.33 & 01.43 & 01.79 & 01.45 & 07.14 \\
\hline & $8(7.50-8.49)$ & 23.86 & 20.82 & 22.27 & 24.06 & 20.00 & 21.91 \\
\hline & $9(8.50-9.49)$ & 24.02 & 25.93 & 24.64 & 25.94 & 24.14 & 25.19 \\
\hline & $10(9.50-10.49)$ & 29.91 & 29.61 & 27.46 & 25.56 & 28.19 & 29.28 \\
\hline & $11(10.50-11.49)$ & 13.99 & 15.30 & 24.20 & 22.66 & 26.22 & 16.48 \\
\hline \multirow[t]{3}{*}{ School shift } & Morning & 50.07 & 49.46 & 48.79 & 44.88 & 45.54 & 49.11 \\
\hline & Afternoon & 49.93 & 50.54 & 51.21 & 51.74 & 51.73 & 50.54 \\
\hline & All day & 0.00 & 0.00 & 0.00 & 03.38 & 02.73 & 00.36 \\
\hline \multirow{5}{*}{$\begin{array}{l}\text { Family income } \\
\text { quintiles }\end{array}$} & $1^{\text {st }}$ & 40.93 & 26.07 & 23.51 & 20.58 & 20.28 & 28.98 \\
\hline & $2^{\text {nd }}$ & 37.65 & 28.36 & 19.26 & 17.78 & 18.51 & 28.81 \\
\hline & $3^{\text {rd }}$ & 16.05 & 23.16 & 19.85 & 18.79 & 21.12 & 20.70 \\
\hline & $4^{\text {th }}$ & 04.85 & 17.12 & 18.17 & 21.79 & 21.24 & 14.62 \\
\hline & $5^{\text {th }}$ & 00.52 & 05.29 & 19.21 & 21.06 & 18.84 & 06.89 \\
\hline \multirow[t]{3}{*}{ Weight status } & Not overweight & 71.13 & 75.42 & 67.75 & 62.32 & 65.58 & 72.43 \\
\hline & Overweight not obese & 17.83 & 08.58 & 19.46 & 23.00 & 20.28 & 13.38 \\
\hline & Obese & 11.04 & 16.01 & 12.79 & 14.69 & 14.14 & 14.19 \\
\hline
\end{tabular}

${ }^{1}$ Due to implausibly low $(<4)$ total frequency of foods and beverages reported for $24 \mathrm{~h}$. 
Table 4. Mean frequency (standard error) of food consumption per day by survey year and average annual change assuming linear time trend over the 2002-2015 period.

\begin{tabular}{|c|c|c|c|c|c|c|c|}
\hline \multirow{2}{*}{ Food } & \multicolumn{5}{|c|}{ Survey year } & \multicolumn{2}{|c|}{ annual change $(\%)$} \\
\hline & 2002 & 2007 & 2013 & 2014 & 2015 & $95 \% \mathrm{CI}$ & p \\
\hline Yoghurt & $\begin{array}{c}0.840 \\
(0.041)\end{array}$ & $\begin{array}{c}0.450 \\
(0.026)\end{array}$ & $\begin{array}{c}0.480 \\
(0.021)\end{array}$ & $\begin{array}{c}0.423 \\
(0.019)\end{array}$ & $\begin{array}{c}0.408 \\
(0.021)\end{array}$ & $\begin{array}{c}-2.1 \\
(-5.3,1.2)\end{array}$ & 0.134 \\
\hline Fruits & $\begin{array}{l}1.261 \\
(0.067)\end{array}$ & $\begin{array}{c}0.855 \\
(0.066)\end{array}$ & $\begin{array}{c}0.462 \\
(0.020)\end{array}$ & $\begin{array}{c}0.544 \\
(0.029)\end{array}$ & $\begin{array}{c}0.521 \\
(0.018)\end{array}$ & $\begin{array}{c}-4.9 \\
(-8.4,0.2)\end{array}$ & 0.065 \\
\hline $\begin{array}{l}\text { Hamburger/ } \\
\text { pizza }\end{array}$ & $\begin{array}{c}0.944 \\
(0.046)\end{array}$ & $\begin{array}{c}0.321 \\
(0.050)\end{array}$ & $\begin{array}{c}0.282 \\
(0.015)\end{array}$ & $\begin{array}{c}0.275 \\
(0.020)\end{array}$ & $\begin{array}{c}0.275 \\
(0.015)\end{array}$ & $\begin{array}{c}-4.1 \\
(-8.2,0.3)\end{array}$ & 0.058 \\
\hline $\begin{array}{l}\text { Meat/chicken/ } \\
\text { fish/seafood }\end{array}$ & $\begin{array}{l}1.940 \\
(0.055)\end{array}$ & $\begin{array}{c}1.189 \\
(0.041)\end{array}$ & $\begin{array}{c}1.001 \\
(0.030)\end{array}$ & $\begin{array}{c}0.952 \\
(0.026)\end{array}$ & $\begin{array}{c}0.981 \\
(0.027)\end{array}$ & $\begin{array}{c}-6.0 \\
(-11.2,-0.8)\end{array}$ & 0.034 \\
\hline Milk/cheese & $\begin{array}{c}0.913 \\
(0.040)\end{array}$ & $\begin{array}{c}0.768 \\
(0.031)\end{array}$ & $\begin{array}{c}0.447 \\
(0.024)\end{array}$ & $\begin{array}{c}0.397 \\
(0.022)\end{array}$ & $\begin{array}{c}0.419 \\
(0.021)\end{array}$ & $\begin{array}{c}-4.2 \\
(-5.7,-2.8)\end{array}$ & 0.003 \\
\hline Dairy products ${ }^{1}$ & $\begin{array}{c}2.548 \\
(0.019)\end{array}$ & $\begin{array}{c}1.982 \\
(0.070)\end{array}$ & $\begin{array}{c}1.337 \\
(0.043)\end{array}$ & $\begin{array}{l}1.308 \\
(0.047)\end{array}$ & $\begin{array}{c}1.291 \\
(0.047)\end{array}$ & $\begin{array}{c}-10.3 \\
(-11.6,-9.0)\end{array}$ & $<0.001$ \\
\hline Cooked beans & $\begin{array}{l}1.570 \\
(0.095)\end{array}$ & $\begin{array}{c}0.901 \\
(0.052)\end{array}$ & $\begin{array}{c}0.821 \\
(0.024)\end{array}$ & $\begin{array}{c}0.806 \\
(0.030)\end{array}$ & $\begin{array}{c}0.830 \\
(0.028)\end{array}$ & $\begin{array}{c}-3.3 \\
(-8.5,1.9)\end{array}$ & 0.136 \\
\hline Fruits/vegetables ${ }^{2}$ & $\begin{array}{c}2.045 \\
(0.080)\end{array}$ & $\begin{array}{c}1.579 \\
(0.079)\end{array}$ & $\begin{array}{c}0.953 \\
(0.033)\end{array}$ & $\begin{array}{c}1.033 \\
(0.044)\end{array}$ & $\begin{array}{l}1.061 \\
(0.035)\end{array}$ & $\begin{array}{c}-7.7 \\
(-13.9,-1.5)\end{array}$ & 0.029 \\
\hline Fast food ${ }^{3}$ & $\begin{array}{c}1.724 \\
(0.070)\end{array}$ & $\begin{array}{c}0.794 \\
(0.080)\end{array}$ & $\begin{array}{c}1.299 \\
(0.058)\end{array}$ & $\begin{array}{c}1.309 \\
(0.055)\end{array}$ & $\begin{array}{c}1.294 \\
(0.055)\end{array}$ & $\begin{array}{c}-1.6 \\
(-10.7,7.4)\end{array}$ & 0.605 \\
\hline Sweets $^{4}$ & $\begin{array}{c}2.656 \\
(0.110)\end{array}$ & $\begin{array}{c}1.994 \\
(0.048)\end{array}$ & $\begin{array}{l}1.384 \\
(0.053)\end{array}$ & $\begin{array}{c}1.332 \\
(0.037)\end{array}$ & $\begin{array}{l}1.318 \\
(0.042)\end{array}$ & $\begin{array}{c}-9.6 \\
(-12.4,-6.8)\end{array}$ & 0.002 \\
\hline Sugary drinks ${ }^{5}$ & $\begin{array}{c}2.831 \\
(0.073)\end{array}$ & $\begin{array}{l}1.800 \\
(0.093)\end{array}$ & $\begin{array}{c}1.157 \\
(0.048)\end{array}$ & $\begin{array}{c}1.119 \\
(0.045)\end{array}$ & $\begin{array}{c}1.192 \\
(0.045)\end{array}$ & $\begin{array}{c}-12.7 \\
(-18.8,-6.5)\end{array}$ & 0.007 \\
\hline Soda & $\begin{array}{c}1.337 \\
(0.050)\end{array}$ & $\begin{array}{c}1.104 \\
(0.060)\end{array}$ & $\begin{array}{c}0.568 \\
(0.035)\end{array}$ & $\begin{array}{c}0.534 \\
(0.034)\end{array}$ & $\begin{array}{c}0.564 \\
(0.032)\end{array}$ & $\begin{array}{c}-6.5 \\
(-8.7,-4.1)\end{array}$ & 0.003 \\
\hline
\end{tabular}

${ }^{1}$ Milk/cheese, yogurt, eggs in 2002; added coffee with milk and omitted eggs in 2007; cheese, eggs and yogurt presented as separate icons in 2013-2015. ${ }^{2}$ Fruits and green leaves/vegetable soup in 2002; in addition to fruits, green leaves, vegetables and vegetable soup presented as separate icons in 2007; fruits, vegetables and green leaves kept in 2013-2015. ${ }^{3}$ Hamburger/pizza and French fries in 2002; salty snacks added in 2007 and instant pasta, nuggets and canned food in 2013-2015. ${ }^{4}$ included chocolate bars and powder in 2002 and 2007; presented four separate icons in 2013-2015: chocolate drinks, biscuits without cream, biscuits with cream and cakes. ${ }^{5}$ Sodas and sugar-added fruit juice.

Source: Authors.

versions of the questionnaire were applied (Table 4). Higher mean values were predominant in the first two surveys (Table 5).

Unadjusted linear trend for the MFC weighted by precision showed statistically significant reductions for the animal proteins which included beef/poultry, fish/seafood and eggs (6\% $\mathrm{p} /$ year $)$, milk/cheese $(4.2 \% \mathrm{p} /$ year $)$, dairy products $(10.3 \% \mathrm{p} /$ year $)$, fruits/vegetables $(7.7 \% \mathrm{p} /$ year), sweets $(9.6 \%$ p/year $)$, sodas $(6.5 \%$ p/year $)$ and sugary drinks (12.7\% p/year) (Table 3$)$. The reductions of $4.1 \% \mathrm{p} /$ year for pizza/hamburger and $2.1 \% \mathrm{p} /$ year for fruits were marginally significant (p-values of 0.058 and 0.065 , respectively).

There was a significantly higher FCR for all food/beverage items reported in the 2002 survey using the typical day question (flagged as $2002^{\mathrm{a}}$ in Table 4) compared to the likely FCR had the question been asked of the previous day instead (flagged as $2002^{\mathrm{b}}$ ). The 2002 and 2007 pen-andpaper questionnaires rendered significantly higher values than the 2013-2015 computer screen prompts for all foods/beverages analysed except yoghurt (penultimate column in Table 4). This comparison used the 2002 interval regression estimate of the hypothetical question on the previous day food consumption. To avoid the uncertainty related to this potential outcome, another comparison was made excluding the 2002 data, i.e. contrasting the 2013-2015 computer screen versus 2007 pen-and-pencil reports, all of which referred to the previous day food consumption. Although the same FCR reduction trend for the later period was confirmed, its magnitude was 
Table 5. Food consumption rate per day: point estimates for each survey year, 2013-2015 vs. 2002 and 2007 post hoc contrast ratios from multiple Poisson regression.

\begin{tabular}{|c|c|c|c|c|c|c|c|}
\hline \multirow[b]{2}{*}{ Food/beverage } & \multirow[b]{2}{*}{ Year } & \multirow[b]{2}{*}{ FCR } & \multicolumn{2}{|c|}{ 95\% CI bound } & \multirow{2}{*}{$\begin{array}{c}\text { SE } \\
\text { MFC }\end{array}$} & \multicolumn{2}{|c|}{ FCRR } \\
\hline & & & Lower & Upper & & $\begin{array}{c}2013-2015 \text { vs. } \\
2002 \& 2007\end{array}$ & $\begin{array}{c}\text { 2013-2015 } \\
\text { vs. } 2007\end{array}$ \\
\hline \multirow[t]{6}{*}{ Yoghurt } & $2002^{1}$ & 0.16 & 0.15 & 0.17 & & 1.02 & 1.10 \\
\hline & $2002^{2}$ & 0.09 & 0.07 & 0.10 & 0.02 & $(0.87,1.19)$ & $(0.92,1.31)$ \\
\hline & 2007 & 0.07 & 0.06 & 0.08 & & & \\
\hline & 2013 & 0.09 & 0.08 & 0.10 & 0.01 & & \\
\hline & 2014 & 0.08 & 0.07 & 0.09 & & & \\
\hline & 2015 & 0.08 & 0.07 & 0.09 & & & \\
\hline \multirow[t]{6}{*}{ Fruits } & $2002^{1}$ & 0.24 & 0.23 & 0.26 & 0.02 & 0.64 & 0.66 \\
\hline & $2002^{2}$ & 0.16 & 0.14 & 0.18 & & $(0.56,0.72)$ & $(0.55,0.80)$ \\
\hline & 2007 & 0.14 & 0.12 & 0.16 & & & \\
\hline & 2013 & 0.09 & 0.07 & 0.10 & 0.01 & & \\
\hline & 2014 & 0.10 & 0.09 & 0.11 & & & \\
\hline & 2015 & 0.09 & 0.08 & 0.10 & & & \\
\hline \multirow[t]{6}{*}{ Hamburger/pizza } & $2002^{1}$ & 0.19 & 0.17 & 0.21 & & 0.62 & 0.81 \\
\hline & $2002^{2}$ & 0.09 & 0.08 & 0.11 & 0.02 & $(0.48,0.79)$ & $(0.58,1.12)$ \\
\hline & 2007 & 0.05 & 0.04 & 0.07 & & & \\
\hline & 2013 & 0.05 & 0.04 & 0.05 & 0.01 & & \\
\hline & 2014 & 0.04 & 0.04 & 0.05 & & & \\
\hline & 2015 & 0.05 & 0.04 & 0.05 & & & \\
\hline \multirow[t]{6}{*}{ Meat, chicken, fish, seafood } & $2002^{1}$ & 0.19 & 0.18 & 0.20 & & 0.72 & 0.83 \\
\hline & $2002^{2}$ & 0.13 & 0.13 & 0.14 & 0.03 & $(0.68,0.77)$ & $(0.77,0.89)$ \\
\hline & 2007 & 0.10 & 0.09 & 0.11 & & & \\
\hline & 2013 & 0.09 & 0.08 & 0.09 & 0.01 & & \\
\hline & 2014 & 0.08 & 0.07 & 0.09 & & & \\
\hline & 2015 & 0.08 & 0.08 & 0.09 & & & \\
\hline \multirow[t]{6}{*}{ Milk/cheese } & $2002^{1}$ & 0.181 & 0.171 & 0.192 & & 0.28 & $0.38(0.33$ \\
\hline & $2002^{2}$ & 0.12 & 0.11 & 0.12 & 0.02 & $(0.25,0.32)$ & $0.44)$ \\
\hline & 2007 & 0.063 & 0.059 & 0.070 & & & \\
\hline & 2013 & 0.026 & 0.023 & 0.030 & 0.01 & & \\
\hline & 2014 & 0.022 & 0.019 & 0.024 & & & \\
\hline & 2015 & 0.023 & 0.021 & 0.026 & & & \\
\hline
\end{tabular}

it continues

smaller and its statistical significance $(\mathrm{P}<0.05)$ included fewer items, namely fruits, meats/fish/ seafood, milk/cheese and other dairy products, sweets, sugary drinks and sodas (last column in Table 4). Among the significant reductions, the largest one was observed for milk/cheese $(62 \%$ with $95 \%$ CI 56-67\%) and the smallest was found for the meats/fish/seafood (17\% with $95 \%$ CI 11-23\%).

\section{Discussion}

The present study provided an example of time trend analysis based on different FFQs, namely pen-and-paper versus computer screen presentation mode, varying number of items within food group over survey years and variations in probabilistic sampling procedures. Despite uneven spacing of the surveys over the 2002-2015 period and above methodological differences, both linear (per year) and contrast type changes were evaluated. To the authors' best knowledge, this is the first time a data synthesis of this kind was published in nutritional epidemiological studies of children and adolescents, although some general recommendations for trend analysis have been provided ${ }^{26}$. 
Table 5. Food consumption rate per day: point estimates for each survey year, 2013-2015 vs. 2002 and 2007 post hoc contrast ratios from multiple Poisson regression.

\begin{tabular}{|c|c|c|c|c|c|c|c|}
\hline \multirow[b]{2}{*}{ Food/beverage } & \multirow[b]{2}{*}{ Year } & \multirow[b]{2}{*}{ FCR } & \multicolumn{2}{|c|}{ 95\% CI bound } & \multirow[b]{2}{*}{$\begin{array}{c}\text { SE } \\
\text { MFC }\end{array}$} & \multicolumn{2}{|c|}{ FCRR } \\
\hline & & & Lower & Upper & & $\begin{array}{c}2013-2015 \text { vs. } \\
2002 \& 2007\end{array}$ & $\begin{array}{c}2013-2015 \\
\text { vs. } 2007\end{array}$ \\
\hline \multirow[t]{6}{*}{ Dairy products } & $2002^{1}$ & 0.17 & 0.16 & 0.17 & & 0.60 & 0.70 \\
\hline & $2002^{2}$ & 0.12 & 0.11 & 0.12 & 0.04 & $(0.55,0.66)$ & $(0.64,0.78)$ \\
\hline & 2007 & 0.08 & 0.08 & 0.09 & & & \\
\hline & 2013 & 0.06 & 0.06 & 0.07 & 0.02 & & \\
\hline & 2014 & 0.06 & 0.05 & 0.06 & & & \\
\hline & 2015 & 0.06 & 0.05 & 0.06 & & & \\
\hline \multirow[t]{6}{*}{ Cooked beans } & $2002^{1}$ & 0.30 & 0.27 & 0.33 & & 0.80 & 0.97 (0.88, \\
\hline & $2002^{2}$ & 0.23 & 0.20 & 0.25 & 0.02 & $(0.74,0.87)$ & 1.08) \\
\hline & 2007 & 0.15 & 0.14 & 0.17 & & & \\
\hline & 2013 & 0.15 & 0.13 & 0.16 & 0.01 & & \\
\hline & 2014 & 0.14 & 0.13 & 0.16 & & & \\
\hline & 2015 & 0.15 & 0.13 & 0.16 & & & \\
\hline \multirow[t]{6}{*}{ Fruits/veg. } & $2002^{1}$ & 0.20 & 0.19 & 0.21 & & 0.66 & 0.95 \\
\hline & $2002^{2}$ & 0.14 & 0.13 & 0.15 & 0.04 & $(0.59,0.73)$ & $(0.84,1.07)$ \\
\hline & 2007 & 0.07 & 0.06 & 0.07 & & & \\
\hline & 2013 & 0.06 & 0.05 & 0.06 & 0.02 & & \\
\hline & 2014 & 0.07 & 0.06 & 0.07 & & & \\
\hline & 2015 & 0.06 & 0.06 & 0.07 & & & \\
\hline \multirow[t]{6}{*}{ Fast food } & $2002^{1}$ & 0.17 & 0.15 & 0.18 & & 0.58 & 0.82 \\
\hline & $2002^{2}$ & 0.09 & 0.08 & 0.10 & 0.04 & $(0.47,0.71)$ & $(0.63,1.06)$ \\
\hline & 2007 & 0.04 & 0.04 & 0.05 & & & \\
\hline & 2013 & 0.04 & 0.04 & 0.04 & 0.02 & & \\
\hline & 2014 & 0.04 & 0.03 & 0.04 & & & \\
\hline & 2015 & 0.04 & 0.03 & 0.04 & & & \\
\hline \multirow[t]{6}{*}{ Sweets } & $2002^{1}$ & 0.26 & 0.25 & 0.28 & & 0.38 & 0.42 \\
\hline & $2002^{2}$ & 0.20 & 0.18 & 0.22 & 0.04 & $(0.35,0.41)$ & $(0.39,0.46)$ \\
\hline & 2007 & 0.16 & 0.15 & 0.17 & & & \\
\hline & 2013 & 0.07 & 0.07 & 0.08 & 0.02 & & \\
\hline & 2014 & 0.07 & 0.06 & 0.07 & & & \\
\hline & 2015 & 0.07 & 0.06 & 0.07 & & & \\
\hline \multirow[t]{6}{*}{ Sugary drinks } & $2002^{1}$ & 0.29 & 0.28 & 0.30 & & 0.50 & 0.62 \\
\hline & $2002^{2}$ & 20.22 & 0.21 & 0.24 & 0.03 & $(0.46,0.54)$ & $(0.56,0.68)$ \\
\hline & 2007 & 0.15 & 0.14 & 0.16 & & & \\
\hline & 2013 & 0.10 & 0.09 & 0.11 & 0.02 & & \\
\hline & 2014 & 0.09 & 0.08 & 0.10 & & & \\
\hline & 2015 & 0.10 & 0.09 & 0.10 & & & \\
\hline \multirow[t]{6}{*}{ Soda } & $2002^{1}$ & 0.27 & 0.25 & 0.29 & & 0.44 & 0.44 \\
\hline & $2002^{2}$ & 0.19 & 0.17 & 0.21 & 0.02 & $(0.40,0.49)$ & $(0.40,0.49)$ \\
\hline & 2007 & 0.19 & 0.17 & 0.20 & & & \\
\hline & 2013 & 0.09 & 0.08 & 0.10 & 0.01 & & \\
\hline & 2014 & 0.08 & 0.07 & 0.09 & & & \\
\hline & 2015 & 0.27 & 0.25 & 0.29 & & & \\
\hline
\end{tabular}

1,2002 indicate Poisson and interval regression estimates, respectively, for that year; FCR $=$ food consumption rate adjusted for sex, age, family income, school shift and day of the week the questionnaire was applied; CI = confidence interval; SE MFC = standard error of the mean food consumption; FCRR = food consumption rate ratio adjusted for age, sex, family income, school shift and day of week the questionnaire was applied.

Source: Authors. 
Several steps were taken to improve the time-related estimates. First, inclusion criteria (public schools only) and exclusion criteria (implausible frequency of total food consumption per day) were used to reduce the analytical sample heterogeneity and thus both known and unknown confounding effects. Second, control variables were used to further reduce the impact of known confounding variables. Third, offset by maximum food/beverage consumption per day allowed comparability of varying number of food components in a food group over survey years. Fourth, survey parameters accounted for unequal selection probability of pupils and higher similarity of their responses within the same school. Fifth, interval regression used the available FFQ data to estimate a likely value of the 2002 survey had it used the same reference period for the food/beverage consumption as the subsequent surveys (i.e. the previous day), thus allowing a more consistent time trend analysis.

The FCR estimation allowed several types of time effects to be analysed: a) overall time trend assuming constant linear change in both unadjusted and adjusted regression analysis, b) the 2007 versus 2002 survey year contrast to evaluate the effect of switching from the typical day to the previous day question of the food/beverage consumption and adding more food items and improving instruction to children before responding these pen-and-paper questionnaires, and c) 2013-2015 versus 2002-2007 contrast to evaluate the impact of changing the questionnaire presentation from pen-and-pencil to computer screen mode.

Non-overlapping CI for adjusted FCR comparing the 2007 versus 2002 survey year indicated a significant reduction in consumption of all foods/beverages analysed, except yoghurt (Table 4). Changing the instruction to answer about typical day food/beverage consumption in 2002 to a previous day consumption in 2007 may have reduced intrusion of some foods which could appear when "typical" was interpreted by child as "possible" over a longer period (e.g. a week) or confounded with desired foods/beverages or simply not understood and ignored. Also, the reduction may be attributed to improved training of the respondents in 2007, including a short reminder of the meaning of food drawings presented as a classroom poster, before answering the PDFQ-3. Another possible explanation is that expanding the number of drawings in the latter version facilitated pupils' understanding of the menu.

The overall unadjusted linear time trend analyses pointed to a downward direction of the
MFC for most of the foods/beverages analysed. However, the linear trend assumption may be too restrictive for some foods/beverages, given the methodological changes made across surveys. For example, 2013-2015 versus 2002-2007 contrast captures the putative effect of changing both the presentation mode and expanding the number of food/beverage options in the questionnaire. Although adjusted FCR in principle accounts for these changes, the contrast estimates are more robust against residual confounding than annualised linear time trend.

The avatar may invoke a more playful than a task-oriented set of mind compared to a classroom teacher's instruction, which in turn may reduce attention and memory effort needed to retrieve information on food consumption on the previous day, thus increasing the omissions in the questionnaire report. Consistently lower MFC obtained by WebCAAFE compared to the penand-pencil versions of the questionnaire for most of the foods analysed pointed to this source of residual confounding. Also, a six-fold increase in implausible food reports in the 2013-2015 period survey compared to the 2002 and 2007 surveys pointed in the same direction as we hypothesize that the screen presentation mode with an avatar in the later period contributed to a less task-oriented environment, thus resulting in lower precision of food reports. We further hypothesize that food report omissions may be more likely than intrusions in such an environment.

Judged by statistical significance of the contrast between the 2013-2015 versus 2002-2007 period, strong evidence was found for reduction in both healthy (fruits, milk/cheese, meats/fish/ seafood) and unhealthy diet markers (sodas, sugary drinks, sweets), whereas such evidence was insufficiently strong for pizza/hamburger, fast food, yoghurt, beans, and fruit and vegetables consumption. The 2013-2015 FCR values, obtained with the same questionnaire presentation mode, showed stable point estimates. Also, expanding the number of food/beverage items from 21 in 2007 to 32 in 2013-2015 should have facilitated the recall of consuming these items the day before. More research is needed to clarify and quantify residual confounding factors influencing food report errors such as omissions and intrusions.

A notable sparsity of time trend studies on food consumption in early school age makes it difficult to compare the present study findings with those of the other trend analysis, such as similar studies with adolescents. Nevertheless, 
the latter sometimes overlaps with the former age band, so an attempt can be made to juxtapose their findings. In Brazil, unhealthy eating habits showed a significant increase, especially among adolescents from low-income families ${ }^{27}$. The consumption of ultra-processed foods has increased at the expense of unprocessed foods such as rice, beans, and fruits, although sugary drinks' intake has decreased in the last decade ${ }^{28,29}$. A similar decreasing trend in the consumption of sugary drinks was found in the USA among children and adolescents ${ }^{30,31}$. European adolescents have increased their intake of fruits and vegetables over the decade of $2010^{32}$. In most developed countries, the consumption of dairy products decreases significantly in adolescence compared to childhood ${ }^{33}$.

Several important limitations of this work should be noted. First, it was impossible to clearly distinguish between period-related and the FFQ method-related changes as they largely coincide. For example, pen-and-paper FFQs with a lower number of food/beverage items were employed in the earlier surveys in 2002 and 2007, whereas the number of these items increased 50\% (from 21 to 32) and their presentation was made on the computer screen in the later 2013-2015 period. Comparing the changes within and between presentation mode provided some clues as to the FCR secular trends adjusted for known confounding factors but it does not eliminate residual confounding. Also, food choices are often correlated and so are their reporting errors but no adjustment was made to accommodate this problem. Furthermore, all questionnaires applied in the present study have the limitations inherent to this dietary assessment method such as memory error ${ }^{1}$.

Some of the limitations were dealt with statistically (FFQ presentation mode end the number of food items per survey) but those inherent to the questionnaire method remained (memory error). Although internal consistency of food reports was not available with a single FFQ application $^{34}$, the latter covered four weekdays and a weekend day (Sunday). Taken together, these information point to a likely underestimate of time trend variance but not necessarily to its bias.

Among the strengths of this work, it is worth highlighting the use of the food questionnaires evaluated for both internal ${ }^{8}$ and external validity $^{10,12,13}$, as well as for usability ${ }^{11}$. Also, the twostage random probabilistic sampling provided a solid representation of the target population in the first two surveys whereas the subsequent surveys achieved almost full population coverage. A large number of participants resulted in high power of statistical tests. Furthermore, the regression approach employed here may have wide applicability for other data syntheses because it used a standard statistical software and procedures to achieve comparability of the impact measures of interest (incidence rates, odds ratios, contrasts).

Web-based surveys have reduced costs and time for the FFQ application and thus made it a viable tool for food consumption monitoring at the population level. Future research needs to refine these instruments regarding respondent cognitive capacity, reliability and validity, based on usability testing and calibration studies.

In conclusion, a regression framework can be used to adjust for methodological differences in the number and/or definition of food items included in a food group. Such differences often arise in longitudinal research with different versions of the same food questionnaire. Both overall time trend and specific contrast analyses may be applied to discern between method-related and time-related components. A significant decrease in consumption of both healthy (fruits, animal protein) and unhealthy foods/beverages (sweets, sodas, sugary drinks) was observed in Florianopolis over the 2002-2015 period.

\section{Collaborations}

All authors were involved in analyzing the studies, reviewing and interpreting the results and writing the manuscript. All authors takes responsibility for all aspects of the reliability and freedom from bias of the data presented and their discussed interpretation. 


\section{Acknowledgements}

We are grateful to Programa Nacional de Pós-Doutorado of Coordenação de Aperfeiçoamento de Pessoal de Nível Superior (PNPD/ CAPES), that granted a postdoctoral scholarship to Rafaela Liberali.

\section{Funding}

These studies were funded by Fundação de Amparo à Pesquisa e Inovação do Estado de Santa Catarina (FAPESC) (grant n. 062/2002), Conselho Nacional de Desenvolvimento Científico e Tecnológico (CNPq) (grant n. 402322/20053), and Ministério da Saúde (Departamento de Ciência, Tecnologia e Insumos Estratégicos DECIT) (grant n. 305148/2011-7).

\section{References}

1. Livingstone MB, Robson PJ, Wallace MW. Issues in dietary intake assessment of children and adolescents. Br J Nutr 2004; 92(Suppl. 2):S213-S222.

2. Illner AK, Freisling H, Boeing H, Huybrechts I, Crispim SP, Slimani N. Review and evaluation of innovative technologies for measuring diet in nutritional epidemiology. Int J Epidemiol 2012; 41(4):1187-1203.

3. Rothausen BW, Matthiessen J, Andersen LF, Brockhoff PB, Tetens I. Dietary patterns on weekdays and weekend days in 4-14-year-old Danish children. Br J Nutr 2013; 109(9):1704-1713.

4. Thompson FE, Subar AF. Dietary Assessment Methodology. In: Coulston AM, Boushey CJ, Ferruzzi MG, editors. Nutrition in the Prevention and Treatment of Disease. Amsterdam: Elsevier; 2013. p. 5-46.

5. Pan American Heath Organization (PAHO). Plan of action for the prevention of obesity in children and adolescents. Washington D.C.: PAHO; 2014. [cited 2019 Sep 13]. Available from: https://www.paho.org/hq/ dmdocuments/2015/Obesity-Plan-Of-Action-Child -Eng-2015.pdf

6. Malta DC, Silva Junior JB. Strategic Action Plan to Combat Non-Communicable Diseases in Brazil after three years of implementation, 2011-2013. Epidemiol Serv Saude 2014; 23(3):389-395.

7. Wijnhoven TM, van Raaij JM, Yngve A, Sjöberg A, Kunešová M, Duleva V, Petrauskiene A, Rito AI, Breda J. WHO European Childhood Obesity Surveillance Initiative: health-risk behaviours on nutrition and physical activity in 6-9-year-old schoolchildren. $\mathrm{Pu}$ blic Health Nutr 2015; 18(17):3108-3124.

8. Barros MVG, Assis MAA, Pires MC, Grossemann S, Vasconcelos FAG, Luna MEP, Barros SSH. Validity of physical activity and food consumption questionnaire for children aged seven to ten years old. Rev Bras Saude Mater Infant 2007; 7(4):437-448.

9. Assis MA, Kupek E, Guimarães D, Calvo MC, Andrade DF, Bellisle F. Test-retest reliability and external validity of the previous day food questionnaire for 7-10-year-old school children. Appetite 2008; 51(1):187-193.

10. Assis MA, Benedet J, Kerpel R, Vasconcelos AF, Di PP, Kupek E. Validation of the third version of the Previous Day Food Questionnaire (PDFQ-3) for 6-to11-years-old schoolchildren. Cad Saude Publica 2009; 25(8):1816-1826.

11. Costa FF, Schmoelz CP, Davies VF, Di Pietro PF, Kupek E, Assis MA. Assessment of diet and physical activity of Brazilian schoolchildren: usability testing of a web-based questionnaire. JMIR Res Protoc 2013; 2(2):e31.

12. Davies VF, Kupek E, Assis MA, Natal S, Di Pietro PF, Baranowski T. Validation of a web-based questionnaire to assess the dietary intake of Brazilian children aged 7-10 years. J Hum Nutr Diet 2015; 28 (Suppl. 1):93-102.

13. Jesus GM, Assis MAA, Kupek E. Validity and reproducibility of an Internet-based questionnaire (Web-CAAFE) to evaluate the food consumption of students aged 7 to 15 years. Cad Saude Publica 2017; 33(5):e00163016. 
14. Lobo AS, de Assis MAA, Leal DB, Borgatto AF, Vieira FK, Di Pietro PF, Kupek E. Empirically derived dietary patterns through latent profile analysis among Brazilian children and adolescents from Southern Brazil, 2013-2015. PLoS One 2019; 14(1):e0210425.

15. Bainter SA, Curran PJ. Advantages of Integrative Data Analysis for Developmental Research. J Cogn Dev 2015; 16(1):1-10.

16. Bauer DJ, Reyes HLM. Modeling variability in individual development: differences of degree or kind? Child Dev Perspect 2010; 4(2):114-122.

17. Bauer DJ, Gottfredson NC, Dean D, Zucker RA. Analyzing repeated measures data on individuals nested within groups: accounting for dynamic group effects. Psychol Methods 2013; 18(1):1-14.

18. Hussong AM, Curran PJ, Bauer DJ. Integrative data analysis in clinical psychology research. Annu Rev Clin Psychol 2013; 9:61-89.

19. Curran PJ, McGinley JS, Bauer DJ, Hussong AM, Burns A, Chassin L, Sher K, Zucker R. A. Moderated nonlinear factor model for the development of commensurate measures in integrative data analysis. Multivariate Behav Res 2014; 49(3):214-231.

20. de Assis MA, Rolland-Cachera MF, Grosseman S, de Vasconcelos FA, Luna ME, Calvo MC, Barros MV, Pires MM, Bellisle F. Obesity, overweight and thinness in schoolchildren of the city of Florianópolis, Southern Brazil. Eur J Clin Nutr 2005; 59(9):1015-1021.

21. Assis MAA, Kupek E, Guimarães D, Calvo MCM, Andrade DF, Bellisle F. Qualitative analysis of the diet of a probabilistic sample of schoolchildren from Florianópolis, Santa Catarina State, Brazil, using the Previous Day Food Questionnaire. Cad Saude Publica 2010; 26(7):1355-1365.

22. Diep CS, Hingle M, Chen TA, Dadabhoy HR, Beltran A, Baranowski J, Subar AF, Baranowski T. The automated self-administered 24-hour dietary recall for children, 2012, version for youth aged 9 to 11 years: a validation study. J Acad Nutr Diet 2015; 115(10):15911598.

23. Brasil. Ministério da Saúde (MS). Guia alimentar para a população brasileira. Brasília: MS; 2008.

24. Brasil. Ministério da Saúde (MS). Guia alimentar para a população brasileira. 2a ed. Brasília: MS; 2014.

25. Stata Corp. Stata Statistcal Software: Release 13. College Station, TX: Stata Corp LP; 2013.

26. Schnohr CW, Molcho M, Rasmussen M, Samdal O, de Looze M, Levin K, Roberts CJ, Ehlinger V, Krølner R, Dalmasso P, Torsheim T. Trend analyses in the health behaviour in school-aged children study: methodological considerations and recommendations. Eur J Public Health 2015; 25 (Suppl. 2):7-12.
27. Haddad MR, Sarti FM. Sociodemographic determinants of health behaviors among Brazilian adolescents: trends in physical activity and food consumption, 2009-2015. Appetite 2020; 144:104454.

28. Martins APB, Levy RB, Claro RM, Moubarac JC, Monteriro CA. Increased contribution of ultra-processed food products in the Brazilian diet (1987-2009). Rev Saude Publica 2013; 47(4):656-665.

29. Ventura Barbosa Gonçalves H, Canella DS, Bandoni DH. Temporal variation in food consumption of Brazilian adolescents (2009-2015). PLoS One 2020; 15(9):e0239217.

30. Beck AL, Martinez S, Patel AI, Fernandez A. Trends in sugar-sweetened beverage consumption among California children. Public Health Nutr 2020; 23(16):28642869.

31. Bleich SN, Vercammen KA, Koma JW, Li Z. Trends in beverage consumption among children and adults, 2003-2014. Obesity 2018; 26(2):432-441.

32. Vereecken C, Pedersen TP, Ojala K, Krølner R, Dzielska A, Ahluwalia N, Giacchi M, Kelly C. Fruit and vegetable consumption trends among adolescents from 2002 to 2010 in 33 countries. Eur J Public Health 2015 25 (Suppl. 2):16-19.

33. Dror DK, Allen LH. Dairy product intake in children and adolescents in developed countries: trends, nutritional contribution, and a review of association with health outcomes. Nutr Rev 2014; 72(2):68-81.

34. Gibson RS, Charrondiere UR, Bell W. Measurement Errors in Dietary Assessment Using Self-Reported 24Hour Recalls in Low-Income Countries and Strategies for Their Prevention. Adv Nutr 2017; 8:980-991.

Article submitted 14/09/2020

Approved 07/01/2021

Final version submitted 09/01/2021

Chief editors: Romeu Gomes, Antônio Augusto Moura da Silva 